\title{
ANALISIS PENGARUH MANAJEMEN MODAL KERJA TERHADAP PROFITABILITAS DALAM INDUSTRI CONSUMER GOODS YANG TERDAFTAR DI BURSA EFEK INDONESIA
}

\author{
Iswandi \\ Jurusan Akuntansi, Fakultas Ekonomi dan Bisnis, Universitas Bina Nusantara \\ Jln. K.H. Syahdan No. 9, Palmerah, Jakarta Barat 11480 \\ iswandi@binus.ac.id
}

\begin{abstract}
In this paper we evaluate the relathionship between working capital management and corporate profitability. We used a sample of 29 companies in consumer goods industry listed in the Bursa Efek Indonesia for the period of 2006 - 2008. The results of the evaluation showed that there is statistical significance between profitability, measured through gross profit, and the cash conversion cycle. Empirical findings show that NDAR, NDI, NDAP affect firm profitability negatively, while CCC affects firm profitability positively.
\end{abstract}

Keywords: working capital, Profitability, Cash Conversion Cycle (CCC), Number of Days Account Receivable (NDAR), Number of Days Inventory (NDI), Number of Days Account Payable (NDAP), Bursa Efek Indonesia

\begin{abstract}
ABSTRAK
Penelitian ini mengevaluasi hubungan antara manajemen modal kerja dan profitabilitas industri. Penelitian ini menggunakan sampel 29 perusahaan dalam industri barang kosumen yang terdaftar pada Bursa Efek Indonesia selama 2006 - 2008. Hasil penelitian menunjukkan bahwa ada signifikansi statistik antara profitabilitas, yang diukur melalui laba kotor, dan siklus konversi kas. Temuan empiris menunjukkan bahwa NDAR, NDI, NDAP memengaruhi profitabilitas perusahaan secara negatif, sedangkan CCC memengaruhi profitabilitas perusahaan secara positif.
\end{abstract}

Kata kunci: modal kerja, Profitabilitas, Siklus Konversi Kas (CCC), Jumlah Hari Piutang (NADR), Jumlah Hari Inventori (NDI), Jumlah Hari Akun Terhutang (NADP), Bursa Efek Indonesia 


\section{PENDAHULUAN}

Dalam menjalankan aktivitas operasi perusahaan sehari-hari, modal kerja merupakan elemen yang penting. Modal kerja diperlukan oleh perusahaan untuk memastikan bahwa perusahaan dapat melanjutkan kegiatan operasinya sehari-hari dan mempunyai dana yang cukup untuk memenuhi hutang jangka pendek yang jatuh tempo dan beban operasi yang akan muncul. Kekurangan modal kerja merupakan masalah yang serius dalam sebuah perusahaan karena menyebabkan kesulitan menjalankan kegiatan operasional dan tidak mampu membayar hutang yang telah jatuh tempo, sehingga perusahaan akan kehilangan kepercayaan dari para kreditor.

Siklus penerimaan kas sangatlah penting, terlebih lagi dalam industri consumer goods, mengingat produk yang dihasilkan merupakan kebutuhan konsumen sehari-hari, sehingga permintaan konsumen akan produk begitu besar. Untuk memenuhi kebutuhan konsumen sehari-hari tersebut, perusahaan melakukan peningkatan kegiatan produksi, penjualan dan distribusi sehingga kegiatan tersebut berjalan dengan volume yang sesuai. Manajemen modal kerja sangat diperlukan dalam industri agar perusahaan dapat melakukan kegiatan operasinya sehari-hari tanpa mengalami hambatan. Dari hal tersebut di atas, dapat dilihat bahwa manajemen modal kerja sangat membantu perusahaan dalam meningkatkan kepercayaan para kreditor dan pelanggan, dimana kepercayaan ini akan meningkatkan nilai perusahaan atau corporate value yang tentunya akan memberikan kontribusi dalam meningkatkan profitabilitas perusahaan.

Sampel yang digunakan adalah perusahaan-perusahaan consumer goods yang terdaftar di Bursa Efek Indonesia (BEI) dari tahun 2006-2008. Dalam menilai manajemen modal kerja digunakan indikator Cash Conversion Cycle (CCC), Number of Days Account Receivable (NDAR), Number of Days Inventory (NDI), dan Number of Days Account Payable (NDAP). Untuk mengukur profitabilitas, digunakan Gross Profit. Selain itu, digunakan beberapa variabel kontrol yaitu pertumbuhan penjualan, ukuran perusahaan (total aset perusahaan), dan rasio leverage, yaitu rasio hutang jangka panjang dibandingkan dengan total aset perusahaan.

Berdasarkan latar belakang di atas, dan cakupan ruang lingkup yang digunakan, dirumuskan beberapa masalah, yaitu: (1) bagaimana pengaruh Cash Conversion Cycle (CCC) terhadap Gross Profit; (2) bagaimana pengaruh Number of Days Account Receivable (NDAR) terhadap Gross Profit; (3) bagaimana pengaruh Number of Days Inventory (NDI) terhadap Gross Profit; dan (4) bagaimana pengaruh Number of Days Account Payable (NDAP) terhadap Gross Profit. Tujuan dari penelitian ini adalah untuk mengetahui pengaruh manajemen modal kerja terhadap profitabilitas perusahaan. Penelitian ini menggunakan 1 variabel dependen, 4 variabel independen, dan 3 variabel kontrol dengan menggunakan model regresi linier.

Modal kerja bersih perusahaan sering kali didefinisikan sebagai selisih antara aktiva lancar dengan utang lancar. Selama aktiva lancar melebih jumlah utang lancar, maka perusahaan memiliki modal kerja bersih tertentu, yang jumlahnya sangat ditentukan oleh jenis usaha dari masing-masing perusahaan. Modal kerja dibagi menjadi dua, yaitu modal kerja kotor dan modal kerja bersih. Modal kerja kotor (gross working capital) adalah total seluruh aset lancar yang dimiliki oleh perusahaan, sedangkan modal kerja bersih (net working capital) adalah dana yang dimiliki suatu perusahaan untuk melanjutkan kegiatan operasinya sehari-hari, dengan cara mengurangi jumlah aktiva lancar dengan hutang lancar, dimana dana tersebut merepresentasikan likuiditas dari sebuah perusahaan. Selain itu, aktiva lancar dan hutang lancar mempunyai tiga akun yang mempunyai aspek kepentingan secara khusus. Tiga akun tersebut adalah account receivable, inventory, dan account payable.

Secara teoretis, manajemen modal kerja yang baik dalam suatu perusahaan dapat meningkatkan profitabilitas perusahaan. Modal kerja membantu meningkatkan kepercayaan dari 
investor dan pelanggan, serta meningkatkan efisiensi operasi perusahaan, dimana hal-hal ini akan meningkatkan nilai perusahaan atau corporate value yang akan membantu dalam meningkatkan profitabilitas perusahaan.

Beberapa penelitian yang pernah dilakukan untuk melihat hubungan antara manajemen modal kerja dengan profitabilitas, adalah: (1) Samiloglu dan Demirgunes (2008), yang meneliti pengaruh manajemen modal kerja terhadap profitabilitas perusahaan di Turki. Penelitian ini menyimpulkan bahwa manajemen modal kerja mempunyai pengaruh yang positif terhadap profitabilitas perusahaan. (2) Lazaridis dan Tryfonidis (2006), yang meneliti hubungan antara manajemen modal kerja dengan profitabilitas pada Athens Stock Exchange. Penelitian ini menyimpulkan adanya pengaruh signifikan antara profitabilitas, yang diukur melalui gross operating profit, dengan cash conversion cycle. (3) Teruel dan Solano (2006), yang melakukan penelitian pada perusahaan Spanyol untuk melihat hubungan antara manajemen modal kerja dengan profitabilitas perusahaan, dan menyimpulkan bahwa number of days in account receivables, number of days in inventory, dan cash conversion cycle mempunyai hubungan negatif yang signifikan terhadap profitabilitas perusahaan.

Penelitian ini merupakan replikasi dari penelitian sebelumnya. Pengukuran manajemen modal kerja ini sering dilakukan oleh peneliti sebelumnya dengan menggunakan cash conversion cycle dan komponen-komponennya. Cash conversion cycle berkaitan dengan waktu yang dibutuhkan perusahaan dari pengeluaran sampai dengan penerimaan kas. Semakin lambat sirkulasi kas yang terjadi, atau semakin besar nilai cash conversion cycle, maka akan semakin menghambat mengalirnya dana modal kerja. Hal ini juga akan mengakibatkan menurunnya kegiatan operasional perusahaan yang pada akhirnya akan menurunkan volume penjualan dan sekaligus menurunkan laba yang dihasilkan oleh perusahaan. Sehingga dapat disimpulkan bahwa semakin kecil cash conversion cycle, semakin tinggi pula profitabilitas yang dihasilkan.

Number of Days Account Receivable berkaitan dengan waktu yang dibutuhkan oleh perusahaan dalam mengonversikan piutang menjadi kas yang dibutuhkan sebagai dana perusahaan. Semakin lama waktu yang dibutuhkan untuk mengubah piutang menjadi kas, semakin lama pula perusahaan menerima kas yang akan dijadikan sebagai dana modal kerja, dan hal ini akan mengakibatkan penurunan kegiatan operasional perusahaan, yang pada akhirnya akan menurunkan volume penjualan perusahaan dan menurunkan laba yang dihasilkan oleh perusahaan. Maka dapat disimpulkan bahwa semakin cepat piutang tersebut dikumpulkan, atau semakin kecil nilai Number of Days Account Receivable, semakin besar pula profitabilitas yang dihasilkan oleh perusahaan.

Number of Days Inventory berkaitan dengan waktu yang dibutuhkan perusahaan dalam menahan persediaan barang yang ada dalam gudang. Semakin lambat perusahaan menahan persediaan barangnya, maka akan menurunkan kas yang dihasilkan dari penjualan persediaan tersebut, dimana hal ini akan berdampak pada pengurangan dana untuk modal kerja, dan menurunkan kegiatan operasional perusahaan. Selanjutnya hal ini akan berdampak pada turunnya volume penjualan perusahaan yang sekaligus akan menurunkan laba yang dihasilkan oleh perusahaan. Karena itulah dapat disimpulkan bahwa semakin kecil angka Number of Days Inventory, semakin tinggi pula profitabilitas yang dihasilkan oleh perusahaan.

Number of Days Account Payable berkaitan dengan waktu yang dibutuhkan perusahaan untuk melunasi account payable kepada para kreditor, semakin lama waktu yang dibutuhkan oleh perusahaan dalam melunasi hutang-hutangnya, maka akan semakin menurunkan kepercayaan dari para kreditor yang pada akhirnya akan menurunkan nilai perusahaan itu sendiri. Hal ini akan menurunkan dana modal kerja yang diperoleh dari pihak luar, dan menurunkan kegiatan operasional perusahaan. Selanjutnya hal ini akan berdampak pada menurunnya volume penjualan perusahaan dan sekaligus menurunkan laba yang dihasilkan oleh perusahaan. Sehingga dapat disimpulkan bahwa semakin kecil angka Number of Days Account Payable ini, semakin tinggi pula profitabilitas yang dihasilkan oleh perusahaan. 
Berdasarkan teori-teori di atas dan penelitian-penelitian yang telah dilakukan sebelumnya, maka penulis menyimpulkan hipotesis sebagai berikut:

H1 : Cash Conversion Cycle (CCC) berpengaruh negatif terhadap Gross Profit

H2: Number of Days Account Receivable (NDAR) berpengaruh negatif terhadap Gross Profit

H3 : Number of Days Inventory (NDI) berpengaruh negatif terhadap Gross Profit

H4 : Number of Days Account Payable (NDAP) berpengaruh negatif terhadap Gross Profit

\section{METODE}

Sampel yang digunakan adalah 29 perusahaan dari populasi 35 perusahaan dalam industri consumer goods yang terdaftar di BEI dari periode 2006-2008. Data yang digunakan adalah laporan keuangan tahunan perusahaan dari tahun 2006-2008, yang diperoleh dari database BEI.

Pengumpulan sampel menggunakan metode purposive sampling, yaitu sampling yang dilakukan dengan pertimbangan tertentu atas populasi, dengan kriteria yaitu: (1) merupakan perusahaan yang termasuk dalam kategori industri consumer goods; (2) telah terdaftar di Bursa Efek Indonesia minimal sejak tahun 2006; (3) perusahaan yang mempunyai nilai Gross Profit yang positif; (4) perusahaan yang memublikasikan secara lengkap laporan keuangan tahunan untuk periode 31 Desember 2006-2008 yang dinyatakan dalam mata uang IDR.

Dari metode tersebut diperoleh sampel 29 perusahaan. Perusahaan yang tidak memenuhi kriteria tersebut adalah Ades Waters Indonesia Tbk, Davomas Abadi Tbk, Sekar Bumi Tbk, BristolMyers Squibb Indonesia Tbk (PS), Kedaung Indah Can Tbk, dan Sara Lee Body Care Indonesia Tbk.

\section{Operasionalisasi Variabel}

Tabel 1 menjelaskan operasionalisasi seluruh variabel yang digunakan dalam penelitian ini.

Tabel 1 Operasionalisasi seluruh variabel

\begin{tabular}{|c|c|c|c|c|}
\hline Jenis Variabel & Variabel & Definisi & Pengukuran & Sumber Data \\
\hline $\begin{array}{c}\text { Variabel } \\
\text { Dependen }\end{array}$ & $\begin{array}{l}\text { Gross Profit } \\
\text { (NLGP) }\end{array}$ & $\begin{array}{l}\text { Laba kotor yang dihasilkan oleh } \\
\text { perusahaan }\end{array}$ & $\begin{array}{l}\text { Natural log dari (Net Sales - } \\
\text { COGS) }\end{array}$ & $\begin{array}{l}\text { Laporan Keuangan } \\
\text { Perusahaan }\end{array}$ \\
\hline \multirow[t]{3}{*}{$\begin{array}{c}\text { Variabel } \\
\text { Independen }\end{array}$} & $\begin{array}{c}\text { Number of days } \\
\text { Account Receivable } \\
\text { (NDAR) }\end{array}$ & $\begin{array}{l}\text { Periode rata-rata yang diperlukan } \\
\text { untuk mengumpulkan piutang }\end{array}$ & $\begin{array}{l}\text { (Rata-rata piutang x 365)/ } \\
\text { Penjualan }\end{array}$ & $\begin{array}{l}\text { Laporan Keuangan } \\
\text { Perusahaan }\end{array}$ \\
\hline & $\begin{array}{c}\text { Number of days } \\
\text { Account Payable } \\
\text { (NDAP) }\end{array}$ & $\begin{array}{l}\text { Periode rata-rata pembayaran } \\
\text { hutang }\end{array}$ & $\begin{array}{l}\text { (Rata-rata hutang x 365)/ } \\
\text { COGS }\end{array}$ & $\begin{array}{l}\text { Laporan Keuangan } \\
\text { Perusahaan }\end{array}$ \\
\hline & $\begin{array}{l}\text { Number of days } \\
\text { Inventory (NDI) }\end{array}$ & $\begin{array}{l}\text { Periode rata-rata menahan } \\
\text { persediaan barang di gudang }\end{array}$ & $\begin{array}{l}\text { (Rata-rata persediaan x 365) / } \\
\text { COGS }\end{array}$ & $\begin{array}{l}\text { Laporan Keuangan } \\
\text { Perusahaan }\end{array}$ \\
\hline $\begin{array}{c}\text { Variabel } \\
\text { Independen }\end{array}$ & $\begin{array}{l}\text { Cash Conversion } \\
\text { Cycle }(\mathrm{CCC})\end{array}$ & $\begin{array}{l}\text { Jangka waktu sejak dilakukan } \\
\text { pengeluaran tunai untuk sumber } \\
\text { dana produksi hingga diterima } \\
\text { uang hasil penjualan dari } \\
\text { produksi }\end{array}$ & NDAR + NDI - NDAP & $\begin{array}{l}\text { Laporan Keuangan } \\
\text { Perusahaan }\end{array}$ \\
\hline \multirow[t]{3}{*}{$\begin{array}{l}\text { Variabel } \\
\text { Kontrol }\end{array}$} & $\begin{array}{l}\text { Sales Growth } \\
\text { (SGROWTH) }\end{array}$ & Pertumbuhan Penjualan & (Sales1 - Sales0) / Sales0 & $\begin{array}{l}\text { Laporan Keuangan } \\
\text { Perusahaan }\end{array}$ \\
\hline & $\begin{array}{l}\text { Ukuran Perusahaan } \\
\text { (NLA) }\end{array}$ & Ukuran Perusahaan & $\begin{array}{l}\text { Natural log dari total aset } \\
\text { perusahaan }\end{array}$ & \multirow{2}{*}{$\begin{array}{l}\text { Laporan Keuangan } \\
\text { Perusahaan } \\
\text { Laporan Keuangan } \\
\text { Perusahaan }\end{array}$} \\
\hline & Debt Ratio (DEBT) & Rasio Leverage & Long Term Debt / Total Asset & \\
\hline
\end{tabular}


Analisis menggunakan metode analisis regresi berganda. Metode ini sesuai dengan metode dari penelitian-penelitian sebelumnya, yang digunakan oleh Lazaridis dan Tryfonidis (2006), Samiloglu dan Demirgunes (2008), dan Teruel dan Solano (2006). Model analisis regresi linier berganda yang digunakan adalah:

Model $1: N L G P=b_{0}+b_{1} C C C+b_{2} S G R O W T H+b_{3} N L A+b_{4} D E B T+\varepsilon$

Model $2: N L G P=b_{0}+b_{1} N D A R+b_{2} S G R O W T H+b_{3} N L A+b_{4} D E B T+\varepsilon$

Model $3: N L G P=b_{0}+b_{1} N D I+b_{2} S G R O W T H+b_{3} N L A+b_{4} D E B T+\varepsilon$

Model $4: N L G P=b_{0}+b_{1} N D A P+b_{2} S G R O W T H+b_{3} N L A+b_{4} D E B T+\varepsilon$

Keterangan:

NLGP : Gross Profit

CCC : Cash Conversion Cycle

NDAR : Number of Days Account Receivable

NDI : Number of Days Inventory

NDAP : Number of Days Account Payable

SGROWTH : Sales Growth

NLA : Ukuran Perusahaan

DEBT : Leverage ratio, yaitu Debt Ratio, dimana total hutang jangka panjang dibagi dengan total aset.

Pengujian hipotesis pertama dilakukan dengan menggunakan formulasi sebagai berikut:

$\mathrm{H}_{01}$ : Cash Conversion Cycle (CCC) tidak berpengaruh negatif terhadap Gross Profit

$\mathrm{H}_{\mathrm{a} 1}$ : Cash Conversion Cycle (CCC) berpengaruh negatif terhadap Gross Profit

Kriteria pengujian yang digunakan untuk menerima atau menolak hipotesis $\left(\mathrm{H}_{\mathrm{a} 1}\right)$ di atas adalah: jika koefisien regresi pada model (1) bertanda negatif dan signifikan secara statistis pada level $10 \%, 5 \%$, atau 1\%, maka Cash Conversion Cycle (CCC) berpengaruh negatif terhadap Gross Profit.

Pengujian hipotesis kedua dilakukan dengan menggunakan formulasi sebagai berikut:

$\mathrm{H}_{02}$ : Number of Days Account Receivable (NDAR) tidak berpengaruh negatif terhadap Gross Profit

$\mathrm{H}_{\mathrm{a} 2}$ : Number of Days Account Receivable (NDAR) berpengaruh negatif terhadap Gross Profit

Kriteria pengujian yang digunakan untuk menerima atau menolak hipotesis $\left(\mathrm{H}_{\mathrm{a} 2}\right)$ di atas adalah: jika koefisien regresi pada model (1) bertanda negatif dan signifikan secara statistis pada level $10 \%, 5 \%$, atau 1\%, maka Number of Days Account Receivable (NDAR)) berpengaruh negatif terhadap Gross Profit.

Pengujian hipotesis ketiga dilakukan dengan menggunakan formulasi sebagai berikut:

$\mathrm{H}_{03}$ : Number of Days Inventory (NDI) tidak berpengaruh negatif terhadap Gross Profit

$\mathrm{H}_{\mathrm{a} 3}$ : Number of Days Inventory (NDI) berpengaruh negatif terhadap Gross Profit

Kriteria pengujian yang digunakan untuk menerima atau menolak hipotesis $\left(\mathrm{H}_{\mathrm{a} 3}\right)$ di atas adalah: jika koefisien regresi pada model (1) bertanda negatif dan signifikan secara statistis pada level $10 \%, 5 \%$, atau 1\%, maka Number of Days Inventory (NDI) berpengaruh negatif terhadap Gross Profit.

Pengujian hipotesis keempat dilakukan dengan menggunakan formulasi sebagai berikut:

$\mathrm{H}_{04}$ : Number of Days Account Payable (NDAP) tidak berpengaruh negatif terhadap Gross Profit 
$\mathrm{H}_{\mathrm{a} 4}:$ Number of Days Account Payable (NDAP) berpengaruh negatif terhadap Gross Profit

Kriteria pengujian yang digunakan untuk menerima atau menolak hipotesis $\left(\mathrm{H}_{\mathrm{a} 4}\right)$ di atas adalah: jika koefisien regresi pada model (1) bertanda negatif dan signifikan secara statistis pada level $10 \%, 5 \%$, atau 1\%, maka Number of Days Account Payable (NDAP) berpengaruh negatif terhadap Gross Profit.

\section{HASIL DAN PEMBAHASAN}

\section{Uji Statistik Deskriptif}

Analisis data yang dilakukan dalam bab ini meliputi analisis deskriptif. Hasil uji statistik deskriptif adalah seperti pada Tabel 2 .

Tabel 2 Uji statistik deskriptif

\begin{tabular}{llrrrr}
\hline \multicolumn{1}{c}{ Variabel } & N & Minimum & Maksimum & \multicolumn{1}{c}{ Mean } & Std. Deviasi \\
\hline NLGP & 87 & 24.141 & 29.932 & 26.596 & 1.574 \\
CCC & 87 & -3 & 366 & 117.529 & 72.406 \\
NDAR & 87 & 3 & 123 & 51.069 & 28.730 \\
NDI & 87 & 4 & 371 & 102.483 & 62.096 \\
NDAP & 87 & 2 & 130 & 36.023 & 23.819 \\
SGROWTH & 87 & -0.239 & 1.417 & 0.213 & 0.233 \\
NLA & 87 & 25.144 & 34.310 & 27.604 & 1.450 \\
DEBT & 87 & 0.014 & 0.498 & 0.119 & 0.120 \\
& & & & & \\
\hline
\end{tabular}

NLGOP: natural log dari Gross Profit, CCC: Cash Conversion Cycle, NDAR: Number of Days Account Receivable, NDI : Number of Days Inventory, NDAP : Number of Days Account Payable, SGROWTH : Sales Growth / pertumbuhan penjualan, NLA : Ukuran perusahaan, dihitung berdasarkan natural log dari aset perusahaan, DEBT : rasio hutang jangka panjang terhadap total aset.

Berdasarkan Tabel 2, dapat diketahui hasil dari uji statistik deskriptif pada variabel penelitian ini. Variabel dependen, yaitu NLGP atau natural log dari Gross Profit, mempunyai nilai rata-rata sebesar 26.596, yang merupakan natural $\log$ dari nilai laba kotor perusahaan. Nilai minimum dihasilkan oleh Cahaya Kalbar Tbk pada tahun 2006 dan nilai maksimum dihasilkan oleh HM Sampoerna Tbk pada tahun 2008. Standar deviasi dari variabel ini adalah 1.574.

Variabel independen pertama adalah $\mathrm{CCC}$ atau Cash Conversion Cycle, mempunyai rata-rata sebesar 117.529, atau rata-rata siklus konversi kas sebesar 118 hari. Nilai minimum dari CCC dimiliki oleh Indofarma Tbk pada tahun 2007 dan nilai maksimum dari CCC dimiliki oleh BAT Indonesia Tbk pada tahun 2006. Standar deviasi sebesar 72.406. Variabel independen kedua adalah NDAR atau Number of Days Account Receivable, mempunyai rata-rata sebesar 51.069, atau rata-rata periode penagihan piutang sebesar 51 hari. Nilai minimum dari NDAR dimiliki oleh HM Sampoerna Tbk pada tahun 2008 dan nilai maksimum dari NDAR dimiliki oleh Mustika Ratu Tbk pada tahun 2006. Standar deviasi sebesar 28.730 . 
Variabel independen ketiga adalah NDI atau Number of Days Inventory, mempunyai rata-rata sebesar 102.483, atau rata-rata memiliki umur persediaan di gudang sebesar 102 hari. Nilai minimum dari NDI dimiliki oleh Aqua Golden Mississippi Tbk pada tahun 2008 dan nilai maksimum dari NDI dimiliki oleh BAT Indonesia Tbk pada tahun 2006. Standar deviasi sebesar 62.096. Variabel independen keempat adalah NDAP atau Number of Days Account Payable, mempunyai rata-rata sebesar 36.023, atau rata-rata umur utang dagang sebesar 36 hari. Nilai minimum dari NDAP dimiliki oleh Prasidha Aneka Niaga Tbk pada tahun 2008, dan nilai maksimum dari NDAP dimiliki oleh Indofarma Tbk pada tahun 2007. Standar deviasi sebesar 23.819. Variabel kontrol pertama adalah SGROWTH atau Sales Growth, yaitu pertumbuhan penjualan perusahaan dibandingkan dengan tahun sebelumnya. Variabel ini mempunyai nilai rata-rata sebesar 0.213 , atau rata-rata pertumbuhan penjualan sebesar $21.3 \%$. Nilai minimum dari SGROWTH dimiliki oleh BAT Indonesia Tbk pada tahun 2008, dan nilai maksimum dari SGROWTH dimiliki oleh Cahaya Kalbar Tbk pada tahun 2008. Standar deviasi sebesar 0.233

Variabel kontrol kedua adalah NLA atau Natural Log dari Aset, yang menunjukkan ukuran dari suatu perusahaan berdasarkan aset yang dimilikinya. Variabel ini mempunyai nilai rata-rata sebesar 27.604, yang merupakan nilai natural log dari aset perusahaan. Nilai minimum dari NLA dimiliki oleh Pyridam Farma Tbk pada tahun 2006, dan nilai maksimum dari NLA dimiliki oleh Indofood Sukses Makmur Tbk pada tahun 2008. Variabel memiliki standar deviasi sebesar 1.450. Variabel kontrol ketiga adalah DEBT, yang menunjukkan rasio hutang jangka panjang terhadap aset perusahaan. Variabel ini mempunyai nilai rata-rata sebesar 0.119 , atau aset perusahaan rata-rata dibiayai oleh hutang jangka panjang sebesar $11.9 \%$. Nilai minimum dari DEBT dimiliki oleh Mustika Ratu Tbk pada tahun 2006, dan nilai maksimum dari DEBT dimiliki oleh Cahaya Kalbar Tbk pada tahun 2008. Standar deviasi sebesar 0.120.

\section{Uji Normalitas}

Uji normalitas dilakukan dengan menggunakan normal probability plot dan histogram. Hasilnya menunjukkan bahwa persebaran data sesungguhnya mendekati garis diagonal yang menunjukkan bahwa data pada model pertama, kedua, ketiga dan keempat berdistribusi normal.

\section{Uji Asumsi Klasik}

Sebelum model regresi 1, 2, 3, dan 4 digunakan untuk menguji hipotesis terlebih dahulu dilakukan uji asumsi klasik yang terdiri atas uji autokorelasi, Uji Multikolinearitas dan uji heteroskedastisitas.

\section{Uji Autokorelasi}

Uji Autokorelasi menunjukkan hasil seperti pada Tabel 3.

Tabel 3 Hasil Uji Autokorelasi

\begin{tabular}{rr}
\hline Model & Nilai Durbin-Watson \\
\hline Model 1 & 0.909 \\
Model 2 & 0.874 \\
Model 3 & 0.944 \\
Model 4 & 0.936 \\
\hline
\end{tabular}


Sehingga dapat disimpulkan bahwa pada model pertama, kedua, ketiga dan keempat tidak terjadi autokorelasi karena nilai D-W terletak antara -2 dan +2 .

\section{Uji Multikolinearitas}

Uji Multikolinearitas dilakukan dengan melihat variance inflation factor (VIF). Apabila nilai VIF lebih tinggi daripada 0,10 atau VIF lebih kecil daripada 10, dapat disimpulkan tidak terjadi multikolinearitas (Santoso, 2002).

Tabel 4 Hasil Uji Multikolinearitas

\begin{tabular}{cll}
\hline Model & Variabel & VIF \\
\hline Model 1 & CCC & 1.174 \\
& SGROWTH & 1.269 \\
& NLA & 1.046 \\
& DEBT & 1.210 \\
Model 2 & NDAR & 1.505 \\
& SGROWTH & 1.275 \\
& NLA & 1.443 \\
& DEBT & 1.186 \\
Model 3 & NDI & 1.163 \\
& SGROWTH & 1.225 \\
& NLA & 1.015 \\
& DEBT & 1.262 \\
Model 4 & NDAP & 1.140 \\
& SGROWTH & 1.193 \\
& NLA & 1.066 \\
& DEBT & 1.272 \\
\hline
\end{tabular}

Berdasarkan hasil uji multikolinearitas, diperoleh hasil bahwa nilai VIF masing-masing variabel pada model pertama, kedua, ketiga dan keempat terletak antara 0.10 dan 10, maka tidak terjadi multikolinearitas.

\section{Uji Heteroskedastisitas}

Pengujian Heteroskedastisitas ini digunakan untuk mengetahui apakah suatu model regresi memiliki kesamaan atau ketidaksamaan varians. Model regresi yang baik memiliki kesamaan varians atau tidak terjadi heteroskedastisitas. Gambar 1 adalah hasil dari pengujian heteroskedastisitas pada keempat model yang digunakan dalam penelitian ini. 


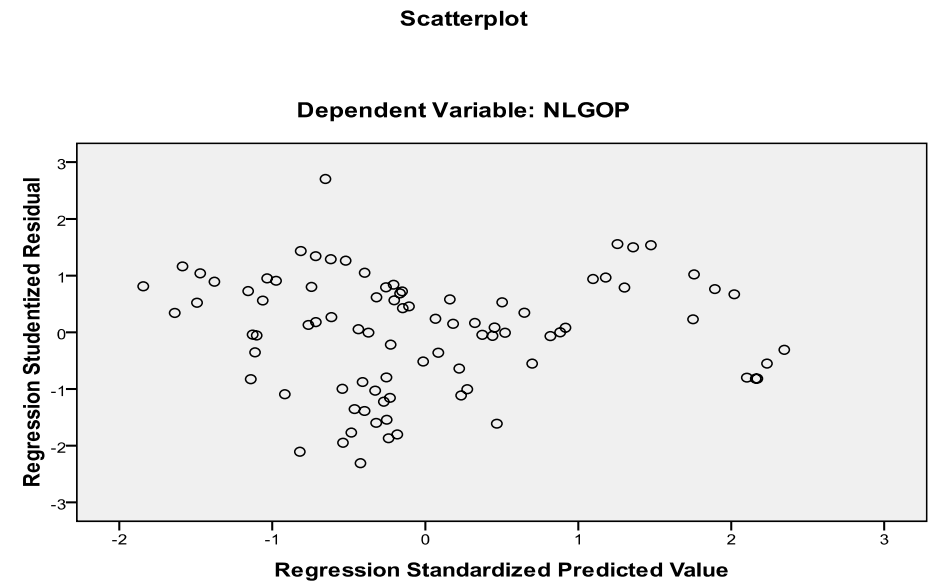

Gambar 1 Hasil pengujian heteroskedastisitas

Dari hasil ini, dapat disimpulkan bahwa pada model pertama, kedua, ketiga dan keempat tidak terjadi heteroskedastisitas.

\section{Analisis Pengujian Hipotesis}

Pengujian hipotesis akan dilakukan dengan metode analisis berganda untuk mengetahui apakah variabel independen berpengaruh terhadap variabel independen atau tidak, serta seberapa besar pengaruh tersebut.

Tabel 5 Hasil Analisis Regresi (Model 1)

Analisis Regresi Antara Variabel CCC, SGROWTH, NLA, dan DEBT Terhadap Variabel NLGP.

$\begin{array}{lccc}N L G P=b_{0}+b_{1} C C C+b_{2} S G R O W T H+b_{3} N L A+b_{4} D E B T+\varepsilon \\ \text { Variabel Independen } & \underline{\text { Koefisien }} & \underline{\mathrm{t} \text {-statistik }} & \underline{\mathrm{t} \text {-sig }} \\ \text { (Constant) } & 0.091 & 0.680 & 0.946 \\ \text { CCC } & -0.001 & -1.495 & 0.139 \\ \text { SGROWTH } & -0.038 & -0.119 & 0.906 \\ \text { NLA } & 0.976 & 20.721 & 0.000 \\ \text { DEBT } & -2.103 & -3.426 & 0.001\end{array}$

F-statistik $=118.343 ; \mathrm{F}$-sig $=0.000$

$\mathrm{R}^{2}=0.852$

NLGOP : natural log dari Gross Profit, CCC: Cash Conversion Cycle,SGROWTH : Sales Growth / pertumbuhan penjualan, NLA : Ukuran perusahaan, dihitung berdasarkan natural log dari aset perusahaan, DEBT : rasio hutang jangka panjang terhadap total aset.

Berdasarkan hasil analisis regresi berganda diatas, dapat dilihat bahwa hasil regresi pada variabel Cash Conversion Cycle adalah bahwa nilai koefisien dari CCC adalah sebesar -0.001, nilai tstatistik sebesar -1.495 dan nilai t-sig sebesar 0.139. Pertama-tama dilakukan pengujian dengan $\alpha=$ $1 \%$. Nilai t-tabel dengan $\mathrm{df}=82$ dan $\alpha=1 \%$ adalah 2.64. Karena nilai t-statistik $(-1.495)>$-t-tabel $(-$ 2.64) dan nilai t-sig (0.139) $>\alpha(0.01)$, maka dapat disimpulkan bahwa CCC tidak berpengaruh negatif secara signifikan terhadap Gross Profit pada tingkat 1\%. Selanjutnya dilakukan pengujian dengan $\alpha=$ $5 \%$. Nilai t-tabel dengan $\mathrm{df}=82$ dan $\alpha=5 \%$ adalah 1.99. Karena nilai t-statistik $(-1.495)>$-t-tabel $(-$ 1.99) dan nilai t-sig $(0.139)>\alpha(0.05)$, maka dapat disimpulkan bahwa CCC tidak berpengaruh negatif 
secara signifikan terhadap Gross Profit pada tingkat 5\%. Terakhir, dilakukan pengujian dengan $\alpha=$ $10 \%$. Nilai t-tabel dengan $\mathrm{df}=82$ dan $\alpha=10 \%$ adalah 1.66 . Karena nilai t-statistik $(-1.495)>$-t-tabel (-1.66) dan nilai t-sig $(0.139)>\alpha(0.1)$, maka dapat disimpulkan bahwa CCC tidak berpengaruh negatif secara signifikan terhadap Gross Profit pada tingkat 10\%. Dari analisis ini, disimpulkan bahwa hipotesis yang menyatakan bahwa Cash Conversion Cycle berpengaruh negatif terhadap profitabilitas perusahaan ditolak.

Hasil regresi pada variabel SGROWTH adalah bahwa nilai koefisien dari SGROWTH adalah sebesar -0.038, nilai t-statistik sebesar -0.119 dan nilai t-sig sebesar 0.906. Pertama-tama dilakukan pengujian dengan $\alpha=1 \%$. Nilai t-tabel dengan $\mathrm{df}=82$ dan $\alpha=1 \%$ adalah 2.64. Karena nilai t-statistik $(-0.119)>$-t-tabel $(-2.64)$ dan nilai t-sig $(0.906)>\alpha(0.01)$, maka dapat disimpulkan bahwa pada model 1 ini, SGROWTH tidak berpengaruh negatif secara signifikan terhadap Gross Profit pada tingkat $1 \%$. Selanjutnya dilakukan pengujian dengan $\alpha=5 \%$. Nilai t-tabel dengan $\mathrm{df}=82$ dan $\alpha=5 \%$ adalah 1.99. Karena nilai t-statistik $(-0.119)>$-t-tabel $(-1.99)$ dan nilai t-sig $(0.906)>\alpha(0.05)$, maka dapat disimpulkan bahwa pada model $1 \mathrm{ini}$, SGROWTH tidak berpengaruh negatif secara signifikan terhadap Gross Profit pada tingkat 5\%. Terakhir, dilakukan pengujian dengan $\alpha=10 \%$. Nilai t-tabel dengan $\mathrm{df}=82(\mathrm{n}-\mathrm{k}-1)$ dan $\alpha=10 \%$ adalah sebesar 1.66. Karena nilai t-statistik $(-0.119)>$-t-tabel $(-$ 1.66) dan nilai t-sig $(0.906)>\alpha(0.1)$, maka dapat disimpulkan bahwa pada model 1 ini, SGROWTH tidak berpengaruh negatif secara signifikan terhadap Gross Profit.

Hasil regresi pada variabel NLA adalah bahwa nilai koefisien dari NLA adalah sebesar 0.976, nilai t-statistik sebesar 20.721 dan nilai t-sig sebesar 0.000. Nilai t-tabel dengan $\mathrm{df}=82(\mathrm{n}-\mathrm{k}-1)$ dan $\alpha$ $=1 \%$ adalah sebesar 2.64. Karena nilai t-statistik $(20.721)>$ t-tabel $(2.64)$ dan nilai t-sig $(0.000)<\alpha$ (0.01), maka dapat disimpulkan bahwa pada model 1 ini, NLA atau ukuran perusahaan berpengaruh positif secara signifikan terhadap Gross Profit pada tingkat 1\%. Hasil regresi pada variabel DEBT adalah bahwa nilai koefisien dari DEBT adalah sebesar -2.103, nilai t-statistik sebesar -3.426 dan nilai $\mathrm{t}$-sig sebesar 0.001. Nilai t-tabel dengan $\mathrm{df}=82(\mathrm{n}-\mathrm{k}-1)$ dan $\alpha=1 \%$ adalah sebesar 2.64. Karena nilai t-statistik $(-3.426)<-t$-tabel $(-2.64)$ dan nilai t-sig $(0.001)<\alpha(0.01)$, maka dapat disimpulkan bahwa pada model 1 ini, DEBT berpengaruh negatif secara signifikan terhadap Gross Profit pada tingkat $1 \%$.

Dari Tabel 5 juga dapat dilihat nilai F-statistik sebesar 118.343 dan nilai F-sig sebesar 0.000. Nilai F-tabel dengan df1 $=4$ dan df $2=82$, serta $\alpha=1 \%$, adalah 3.56. Karena nilai F-statistik (118.343) $>$ F tabel (3.56) dan nilai F-sig $(0.000)<\alpha(0.01)$, maka dapat disimpulkan bahwa secara bersamasama seluruh variabel independen dalam model ini berpengaruh signifikan terhadap profitabilitas perusahaan. Koefisien determinasi $\left(\mathrm{R}^{2}\right)$ adalah sebesar 0.852 , yang artinya sebesar $85.2 \%$ Gross Profit disebabkan oleh CCC, SGROWTH, NLA, dan DEBT, dimana sisanya sebesar $14.8 \%$ ditentukan oleh faktor lain di luar model penelitian ini.

Tabel 6 Hasil Analisis Regresi (Model 2)

Analisis Regresi Antara Variabel NDAR, SGROWTH, NLA, dan DEBT Terhadap Variabel NLGP.

$N L G P=b_{0}+b_{1} N D A R+b_{2} S G R O W T H+b_{3} N L A+b_{4} D E B T+\varepsilon$

$\begin{array}{lrrr}\text { Variabel Independen } & \underline{\text { Koefisien }} & \underline{\text { t-statistik }} & \underline{\text { t-sig }} \\ \text { (Constant) } & 1.343 & 0.828 & 0.410 \\ \text { NDAR } & -0.005 & -1.821 & 0.072 \\ \text { SGROWTH } & -0.069 & -0.216 & 0.830 \\ \text { NLA } & 0.934 & 16.990 & 0.000 \\ \text { DEBT } & -2.049 & -3.394 & 0.001 \\ \text { F-statistik }=120.129 ; \text { F-sig }=0.000 & & & \\ R^{2}=0.854 & & & \end{array}$


NLGOP : natural log dari Gross Profit, NDAR : Number of Days Account Receivable, ,SGROWTH : Sales Growth / pertumbuhan penjualan, NLA : Ukuran perusahaan, dihitung berdasarkan natural log dari aset perusahaan, DEBT : rasio hutang jangka panjang terhadap total aset.

Berdasarkan hasil analisis regresi berganda diatas, dapat dilihat bahwa hasil regresi pada variabel Number of Days Account Receivable adalah bahwa nilai koefisien dari NDAR adalah sebesar -0.005 , nilai t-statistik sebesar -1.821 dan nilai t-sig sebesar 0.072. Pertama-tama dilakukan pengujian dengan $\alpha=1 \%$. Nilai t-tabel dengan $\mathrm{df}=82$ dan $\alpha=1 \%$ adalah 2.64. Karena nilai t-statistik (-1.821)> -t-tabel (-2.64) dan nilai t-sig $(0.072)>\alpha(0.01)$, maka dapat disimpulkan bahwa NDAR tidak berpengaruh negatif secara signifikan terhadap Gross Profit pada tingkat 1\%. Selanjutnya dilakukan pengujian dengan $\alpha=5 \%$. Nilai t-tabel dengan $\mathrm{df}=82$ dan $\alpha=5 \%$ adalah 1.99. Karena nilai t-statistik $(-1.821)>$-t-tabel $(-1.99)$ dan nilai t-sig $(0.072)>\alpha(0.05)$, maka dapat disimpulkan bahwa NDAR tidak berpengaruh negatif secara signifikan terhadap Gross Profit pada tingkat 5\%. Terakhir, dilakukan pengujian dengan $\alpha=10 \%$. Nilai t-tabel dengan $\mathrm{df}=82$ dan $\alpha=10 \%$ adalah 1.66 . Karena nilai t-statistik $(-1.821)<$-t-tabel $(-1.66)$ dan nilai t-sig $(0.072)<\alpha(0.1)$, maka dapat disimpulkan bahwa NDAR berpengaruh negatif secara signifikan terhadap Gross Profit pada tingkat $10 \%$. Dari analisis ini, disimpulkan bahwa hipotesis yang menyatakan bahwa Number of Days Account Receivable berpengaruh negatif terhadap profitabilitas perusahaan diterima $\left(\mathrm{H}_{\mathrm{a} 2}\right.$ diterima atau $\mathrm{H}_{02}$ ditolak).

Hasil regresi pada variabel SGROWTH adalah bahwa nilai koefisien dari SGROWTH adalah sebesar -0.069 , nilai t-statistik sebesar -0.216 dan nilai t-sig sebesar 0.830. Pertama-tama dilakukan pengujian dengan $\alpha=1 \%$. Nilai t-tabel dengan $\mathrm{df}=82$ dan $\alpha=1 \%$ adalah 2.64. Karena nilai t-statistik $(-0.216)>$-t-tabel $(-2.64)$ dan nilai t-sig $(0.830)>\alpha(0.01)$, maka dapat disimpulkan bahwa pada model 2 ini, SGROWTH tidak berpengaruh negatif secara signifikan terhadap Gross Profit pada tingkat $1 \%$. Selanjutnya dilakukan pengujian dengan $\alpha=5 \%$. Nilai t-tabel dengan $\mathrm{df}=82$ dan $\alpha=5 \%$ adalah 1.99. Karena nilai t-statistik $(-0.216)>$-t-tabel $(-1.99)$ dan nilai t-sig $(0.830)>\alpha(0.05)$, maka dapat disimpulkan bahwa pada model 2 ini, SGROWTH tidak berpengaruh negatif secara signifikan terhadap Gross Profit pada tingkat 5\%. Terakhir, dilakukan pengujian dengan $\alpha=10 \%$. Nilai t-tabel dengan $\mathrm{df}=82(\mathrm{n}-\mathrm{k}-1)$ dan $\alpha=10 \%$ adalah sebesar 1.66 . Karena nilai t-statistik $(-0.216)>$-t-tabel $(-$ 1.66) dan nilai t-sig $(0.830)>\alpha(0.1)$, maka dapat disimpulkan bahwa pada model 2 ini, SGROWTH tidak berpengaruh negatif secara signifikan terhadap Gross Profit.

Hasil regresi pada variabel NLA adalah bahwa nilai koefisien dari NLA adalah sebesar 0.934, nilai t-statistik sebesar 16.990 dan nilai t-sig sebesar 0.000. Nilai t-tabel dengan $\mathrm{df}=82(\mathrm{n}-\mathrm{k}-1)$ dan $\alpha$ $=1 \%$ adalah sebesar 2.64. Karena nilai t-statistik (16.990) $>$ t-tabel $(2.64)$ dan nilai t-sig $(0.000)<\alpha$ (0.01), maka dapat disimpulkan bahwa pada model 2 ini, NLA atau ukuran perusahaan berpengaruh positif secara signifikan terhadap Gross Profit pada tingkat 1\%.

Hasil regresi pada variabel DEBT adalah bahwa nilai koefisien dari DEBT adalah sebesar 2.049 , nilai t-statistik sebesar -3.394 dan nilai t-sig sebesar 0.001 . Nilai t-tabel dengan $\mathrm{df}=82(\mathrm{n}-\mathrm{k}-1)$ dan $\alpha=1 \%$ adalah sebesar 2.64. Karena nilai t-statistik $(-3.394)<-$ t-tabel $(-2.64)$ dan nilai $t$-sig $(0.001)<\alpha(0.01)$, maka dapat disimpulkan bahwa pada model 2 ini, DEBT berpengaruh negatif secara signifikan terhadap Gross Profit pada tingkat 1\%.

Dari tabel di atas juga dapat dilihat nilai F-statistik sebesar 120.129 dan nilai F-sig sebesar 0.000. Nilai F-statistik (120.129) $>$ F tabel (3.56) dan nilai F-sig $(0.000)<\alpha(0.01)$, maka dapat disimpulkan bahwa secara bersama-sama, seluruh variabel independen dalam model ini berpengaruh signifikan terhadap profitabilitas perusahaan. Koefisien determinasi $\left(\mathrm{R}^{2}\right)$ adalah sebesar 0.854 , yang artinya sebesar $85.4 \%$ Gross Profit disebabkan oleh NDAR, SGROWTH, NLA, dan DEBT, dimana sisanya sebesar $14.6 \%$ ditentukan oleh faktor lain di luar model penelitian ini. 
Tabel 7 Hasil Analisis Regresi (Model 3)

Analisis Regresi Antara Variabel NDI, SGROWTH, NLA, dan DEBT Terhadap Variabel NLGP.

$\begin{array}{lrrr}N L G P=b_{0}+b_{1} N D I+b_{2} S G R O W T H+b_{3} N L A+b_{4} D E B T+\varepsilon \\ \text { Variabel Independen } & \underline{\text { Koefisien }} & \underline{\text { t-statistik }} & \underline{\text { t-sig }} \\ \text { (Constant) } & -0.139 & -0.107 & 0.915 \\ \text { NDI } & -0.002 & -1.744 & 0.085 \\ \text { SGROWTH } & -0.011 & -0.036 & 0.972 \\ \text { NLA } & 0.986 & 21.354 & 0.000 \\ \text { DEBT } & -2.234 & -3.580 & 0.001\end{array}$

F-statistik $=119.673 ; \mathrm{F}$-sig $=0.000$

$\mathrm{R}^{2}=0.854$

NLGOP : natural log dari Gross Profit, NDI : Number of Days Inventory, ,SGROWTH : Sales Growth / pertumbuhan penjualan, NLA : Ukuran perusahaan, dihitung berdasarkan natural log dari aset perusahaan, DEBT : rasio hutang jangka panjang terhadap total aset.

Berdasarkan hasil analisis regresi berganda diatas, dapat dilihat bahwa hasil regresi pada variabel Number of Days Inventory adalah bahwa nilai koefisien dari NDI adalah sebesar -0.002 , nilai t-statistik sebesar -1.744 dan nilai t-sig sebesar 0.085. Pertama-tama dilakukan pengujian dengan $\alpha=$ $1 \%$. Nilai t-tabel dengan $\mathrm{df}=82$ dan $\alpha=1 \%$ adalah 2.64. Karena nilai t-statistik $(-1.744)>$-t-tabel $(-$ 2.64) dan nilai t-sig $(0.085)>\alpha(0.01)$, maka dapat disimpulkan bahwa NDI tidak berpengaruh negatif secara signifikan terhadap Gross Profit pada tingkat 1\%. Selanjutnya dilakukan pengujian dengan $\alpha=$ $5 \%$. Nilai t-tabel dengan $\mathrm{df}=82$ dan $\alpha=5 \%$ adalah 1.99. Karena nilai t-statistik $(-1.744)>$-t-tabel (1.99) dan nilai t-sig $(0.085)>\alpha(0.05)$, maka dapat disimpulkan bahwa NDI tidak berpengaruh negatif secara signifikan terhadap Gross Profit pada tingkat 5\%. Terakhir, dilakukan pengujian dengan $\alpha=$ $10 \%$. Nilai t-tabel dengan $\mathrm{df}=82$ dan $\alpha=10 \%$ adalah 1.66 . Karena nilai t-statistik $(-1.744)<$-t-tabel $(-1.66)$ dan nilai t-sig $(0.085)<\alpha(0.1)$, maka dapat disimpulkan bahwa NDI berpengaruh negatif secara signifikan terhadap Gross Profit pada tingkat 10\%. Dari analisis ini, disimpulkan bahwa hipotesis yang menyatakan bahwa Number of Days Inventory berpengaruh negatif terhadap profitabilitas perusahaan diterima $\left(\mathrm{H}_{\mathrm{a} 3}\right.$ diterima atau $\mathrm{H}_{03}$ ditolak).

Hasil regresi pada variabel SGROWTH adalah bahwa nilai koefisien dari SGROWTH adalah sebesar -0.011 , nilai t-statistik sebesar -0.036 dan nilai t-sig sebesar 0.972. Pertama-tama dilakukan pengujian dengan $\alpha=1 \%$. Nilai t-tabel dengan $\mathrm{df}=82$ dan $\alpha=1 \%$ adalah 2.64. Karena nilai t-statistik $(-0.036)>$-t-tabel $(-2.64)$ dan nilai t-sig $(0.972)>\alpha(0.01)$, maka dapat disimpulkan bahwa pada model 3 ini, SGROWTH tidak berpengaruh negatif secara signifikan terhadap Gross Profit pada tingkat $1 \%$. Selanjutnya dilakukan pengujian dengan $\alpha=5 \%$. Nilai t-tabel dengan $\mathrm{df}=82$ dan $\alpha=5 \%$ adalah 1.99. Karena nilai t-statistik $(-0.036)>$-t-tabel $(-1.99)$ dan nilai t-sig $(0.972)>\alpha(0.05)$, maka dapat disimpulkan bahwa pada model 3 ini, SGROWTH tidak berpengaruh negatif secara signifikan terhadap Gross Profit pada tingkat 5\%. Terakhir, dilakukan pengujian dengan $\alpha=10 \%$. Nilai t-tabel dengan $\mathrm{df}=82(\mathrm{n}-\mathrm{k}-1)$ dan $\alpha=10 \%$ adalah sebesar 1.66 . Karena nilai t-statistik (-0.036) $>$-t-tabel (1.66) dan nilai t-sig $(0.972)>\alpha(0.1)$, maka dapat disimpulkan bahwa pada model 3 ini, SGROWTH tidak berpengaruh negatif secara signifikan terhadap Gross Profit.

Hasil regresi pada variabel NLA adalah bahwa nilai koefisien dari NLA sebesar 0.986, nilai tstatistik sebesar 21.354 dan nilai t-sig sebesar 0.000. Nilai t-tabel dengan $\mathrm{df}=82(\mathrm{n}-\mathrm{k}-1)$ dan $\alpha=1 \%$ adalah sebesar 2.64. Karena nilai t-statistik (21.354) $>$ t-tabel (2.64) dan nilai t-sig $(0.000)<\alpha(0.01)$, maka dapat disimpulkan bahwa pada model 3 ini, NLA atau ukuran perusahaan berpengaruh positif secara signifikan terhadap Gross Profit pada tingkat 1\%. Hasil regresi pada variabel DEBT adalah bahwa nilai koefisien dari DEBT adalah sebesar -2.234 , nilai t-statistik sebesar -3.580 dan nilai $\mathrm{t}$-sig sebesar 0.001 . Nilai t-tabel dengan $\mathrm{df}=82(\mathrm{n}-\mathrm{k}-1)$ dan $\alpha=1 \%$ adalah sebesar 2.64. Karena nilai $\mathrm{t}-$ 
statistik $(-3.580)<-$ t-tabel $(-2.64)$ dan nilai t-sig $(0.001)<\alpha(0.01)$, maka dapat disimpulkan bahwa pada model 3 ini, DEBT berpengaruh negatif secara signifikan terhadap Gross Profit pada tingkat 1\%.

Dari tabel di atas juga dapat dilihat nilai F-statistik sebesar 119.673 dan nilai F-sig sebesar. Nilai F-statistik (119.673) > F tabel (3.56) dan nilai F-sig $(0.000)<\alpha(0.01)$, maka dapat disimpulkan bahwa secara bersama-sama, seluruh variabel independen dalam model ini berpengaruh signifikan terhadap profitabilitas perusahaan.

Koefisien determinasi $\left(\mathrm{R}^{2}\right)$ adalah sebesar 0.854 , yang artinya sebesar $85.4 \%$ Gross Profit disebabkan oleh NDAR, SGROWTH, NLA, dan DEBT, dimana sisanya sebesar $14.6 \%$ ditentukan oleh faktor lain diluar model penelitian ini.

Tabel 8 Hasil Analisis Regresi (Model 4)

Analisis Regresi Antara Variabel NDAP, SGROWTH, NLA, dan DEBT Terhadap Variabel NLGP

\begin{tabular}{|c|c|c|c|}
\hline \multicolumn{4}{|c|}{$N L G P=b_{0}+b_{1} N D A P+b_{2} S G R O W T H+b_{3} N L A+b_{4} D E B T+\varepsilon$} \\
\hline Variabel Independen & $\underline{\text { Koefisien }}$ & $\underline{\text { t-statistik }}$ & $\underline{\mathrm{t}-\mathrm{sig}}$ \\
\hline (Constant) & 0.346 & 0.235 & 0.815 \\
\hline NDAP & -0.006 & -1.912 & 0.059 \\
\hline SGROWTH & -0.111 & 0.358 & 0.721 \\
\hline NLA & 0.968 & 20.545 & 0.000 \\
\hline DEBT & -2.277 & -3.649 & 0.000 \\
\hline
\end{tabular}

F-statistik $=120.689 ; \mathrm{F}$-sig $=0.000$

$\mathrm{R}^{2}=0.855$

NLGOP : natural log dari Gross Profit, NDAP : Number of Days Account Payable, SGROWTH : Sales Growth / pertumbuhan penjualan, NLA : Ukuran perusahaan, dihitung berdasarkan natural log dari aset perusahaan, DEBT : rasio hutang jangka panjang terhadap total aset.

Berdasarkan hasil analisis regresi berganda diatas, dapat dilihat bahwa hasil regresi pada variabel Number of Days Account Payable adalah bahwa nilai koefisien dari NDAP sebesar -0.006, nilai t-statistik sebesar -1.912 dan nilai t-sig sebesar 0.059. Pertama-tama, dilakukan pengujian dengan $\alpha=1 \%$. Nilai t-tabel dengan $\mathrm{df}=82$ dan $\alpha=1 \%$ adalah 2.64. Karena nilai t-statistik $(-1.912)>$-t-tabel $(-2.64)$ dan nilai t-sig (0.059) $>\alpha(0.01)$, maka dapat disimpulkan bahwa NDAP tidak berpengaruh negatif secara signifikan terhadap Gross Profit pada tingkat 1\%. Selanjutnya dilakukan pengujian dengan $\alpha=5 \%$. Nilai t-tabel dengan $\mathrm{df}=82$ dan $\alpha=5 \%$ adalah 1.99 . Karena nilai t-statistik (-1.912)> -t-tabel (-1.99) dan nilai t-sig (0.059) $>\alpha(0.05)$, maka dapat disimpulkan bahwa NDAP tidak berpengaruh negatif secara signifikan terhadap Gross Profit pada tingkat 5\%. Terakhir, dilakukan pengujian dengan $\alpha=10 \%$. Nilai t-tabel dengan $\mathrm{df}=82$ dan $\alpha=10 \%$ adalah 1.66. Karena nilai tstatistik $(-1.912)<$-t-tabel $(-1.66)$ dan nilai t-sig $(0.059)<\alpha(0.1)$, maka dapat disimpulkan bahwa NDAP berpengaruh negatif secara signifikan terhadap Gross Profit pada tingkat 10\%. Dari analisis ini, disimpulkan bahwa hipotesis yang menyatakan bahwa Number of Days Account Payable berpengaruh negatif terhadap profitabilitas perusahaan diterima $\left(\mathrm{H}_{\mathrm{a} 4}\right.$ diterima atau $\mathrm{H}_{04}$ ditolak).

Hasil regresi pada variabel SGROWTH adalah bahwa nilai koefisien dari SGROWTH adalah sebesar -0.111, nilai t-statistik sebesar -0.358 dan nilai t-sig sebesar 0.721. Pertama-tama, dilakukan pengujian dengan $\alpha=1 \%$. Nilai t-tabel dengan $\mathrm{df}=82$ dan $\alpha=1 \%$ adalah 2.64. Karena nilai t-statistik $(-0.358)>$-t-tabel $(-2.64)$ dan nilai t-sig $(0.721)>\alpha(0.01)$, maka dapat disimpulkan bahwa pada model 4 ini, SGROWTH tidak berpengaruh negatif secara signifikan terhadap Gross Profit pada tingkat $1 \%$. Selanjutnya, dilakukan pengujian dengan $\alpha=5 \%$. Nilai t-tabel dengan $\mathrm{df}=82$ dan $\alpha=5 \%$ adalah 1.99. Karena nilai t-statistik $(-0.358)>$-t-tabel $(-1.99)$ dan nilai t-sig $(0.721)>\alpha(0.05)$, maka 
dapat disimpulkan bahwa pada model 4 ini, SGROWTH tidak berpengaruh negatif secara signifikan terhadap Gross Profit pada tingkat 5\%. Terakhir, dilakukan pengujian dengan $\alpha=10 \%$. Nilai t-tabel dengan $\mathrm{df}=82(\mathrm{n}-\mathrm{k}-1)$ dan $\alpha=10 \%$ adalah sebesar 1.66. Karena nilai t-statistik (-0.358) $>$-t-tabel (1.66) dan nilai t-sig $(0.721)>\alpha(0.1)$, maka dapat disimpulkan bahwa pada model 4 ini, SGROWTH tidak berpengaruh negatif secara signifikan terhadap Gross Profit.

Hasil regresi pada variabel NLA adalah bahwa nilai koefisien dari NLA adalah sebesar 0.968, nilai t-statistik sebesar 20.545 dan nilai t-sig sebesar 0.000. Nilai t-tabel dengan $\mathrm{df}=82(\mathrm{n}-\mathrm{k}-1)$ dan $\alpha$ $=1 \%$ adalah sebesar 2.64. Karena nilai t-statistik (20.545) $>$ t-tabel $(2.64)$ dan nilai t-sig $(0.000)<\alpha$ (0.01), maka dapat disimpulkan bahwa pada model 4 ini, NLA atau ukuran perusahaan berpengaruh positif secara signifikan terhadap Gross Profit pada tingkat 1\%. Hasil regresi pada variabel DEBT adalah bahwa nilai koefisien dari DEBT adalah sebesar -2.277, nilai t-statistik sebesar -3.649 dan nilai $\mathrm{t}$-sig sebesar 0.000 . Nilai t-tabel dengan $\mathrm{df}=82(\mathrm{n}-\mathrm{k}-1)$ dan $\alpha=1 \%$ adalah sebesar 2.64. Karena nilai t-statistik (-3.649) <-t-tabel $(-2.64)$ dan nilai t-sig $(0.000)<\alpha(0.01)$, maka dapat disimpulkan bahwa pada model 4 ini, DEBT berpengaruh negatif secara signifikan terhadap Gross Profit pada tingkat 1\%.

Dari tabel di atas juga dapat dilihat nilai F-statistik sebesar 120.689 dan nilai F-sig sebesar 0.000. Disimpulkan bahwa secara bersama-sama, seluruh variabel independen dalam model ini berpengaruh signifikan terhadap profitabilitas perusahaan.

\section{Pembahasan} berikut.

Berdasarkan analisis regresi berganda di atas, disimpulkan hasil pengujian hipotesis sebagai

Tabel 9 Ringkasan Pengujian Hipotesis Dengan Berbagai Tingkat $\alpha$

\begin{tabular}{ll}
\hline Tingkat Kepercayaan & \multicolumn{1}{c}{ Hasil Pengujian Hipotesis } \\
\hline$\alpha=1 \%$ & $\mathrm{H}_{\mathrm{a} 1}, \mathrm{H}_{\mathrm{a} 2}, \mathrm{H}_{\mathrm{a} 3}$, dan $\mathrm{H}_{\mathrm{a} 4}$ ditolak \\
$\alpha=5 \%$ & $\mathrm{H}_{\mathrm{a} 1}, \mathrm{H}_{\mathrm{a} 2}, \mathrm{H}_{\mathrm{a} 3}, \& \mathrm{H}_{\mathrm{a} 4}$ ditolak \\
$\alpha=10 \%$ & $\mathrm{H}_{\mathrm{a} 1}$ ditolak, tetapi $\mathrm{H}_{\mathrm{a} 2}, \mathrm{H}_{\mathrm{a} 3}$, dan $\mathrm{H}_{\mathrm{a} 4}$ diterima \\
\hline
\end{tabular}

Tabel 10 Ringkasan Pengujian Hipotesis Dengan Tingkat $\alpha=10 \%$

\begin{tabular}{|c|c|c|}
\hline Hipotesis & Hasil Pengujian & Kesimpulan \\
\hline $\begin{array}{l}\mathrm{H} 1: \text { Cash Conversion Cycle } \\
\text { (CCC) berpengaruh negatif } \\
\text { terhadap Gross Profit }\end{array}$ & $\begin{array}{l}\text { Hipotesis ditolak } \\
\left(\mathrm{H}_{\mathrm{a} 1} \text { ditolak atau } \mathrm{H}_{01}\right. \\
\text { tidak ditolak })\end{array}$ & $\begin{array}{l}\text { Cash Conversion Cycle (CCC) berpengaruh negatif } \\
\text { tetapi tidak signifikan terhadap Gross Profit }\end{array}$ \\
\hline $\begin{aligned} \mathrm{H} 2: & \text { Number of Days Account } \\
& \text { Receivable (NDAR) } \\
& \text { berpengaruh negatif } \\
& \text { terhadap Gross Profit }\end{aligned}$ & $\begin{array}{l}\text { Hipotesis diterima } \\
\left(\mathrm{H}_{\mathrm{a} 1} \text { diterima atau }\right. \\
\left.\mathrm{H}_{01} \text { ditolak }\right)\end{array}$ & $\begin{array}{l}\text { Number of Days Account Receivable (NDAR) } \\
\text { berpengaruh negatif dan signifikan terhadap Gross } \\
\text { Profit }\end{array}$ \\
\hline $\begin{aligned} \mathrm{H} 3: \text { Number of Days Inventory } \\
\\
\text { (NDI) berpengaruh negatif } \\
\text { terhadap Gross Profit }\end{aligned}$ & $\begin{array}{l}\text { Hipotesis diterima } \\
\left(\mathrm{H}_{\mathrm{a} 1} \text { diterima atau }\right. \\
\left.\mathrm{H}_{01} \text { ditolak }\right)\end{array}$ & $\begin{array}{l}\text { Number of Days Inventory (NDI) berpengaruh negatif } \\
\text { dan signifikan terhadap Gross Profit }\end{array}$ \\
\hline $\begin{aligned} \mathrm{H} 4: & \text { Number of Days Account } \\
& \text { Payable (NDAP) } \\
& \text { berpengaruh negatif } \\
& \text { terhadap Gross Profit }\end{aligned}$ & $\begin{array}{l}\text { Hipotesis diterima } \\
\left(\mathrm{H}_{\mathrm{a} 1} \text { diterima atau }\right. \\
\left.\mathrm{H}_{01} \text { ditolak }\right)\end{array}$ & $\begin{array}{l}\text { Number of Days Account Payable (NDAP) } \\
\text { berpengaruh negatif dan signifikan terhadap Gross } \\
\text { Profit }\end{array}$ \\
\hline
\end{tabular}


Pada pengujian hipotesis pertama, diketahui bahwa hipotesis yang menyatakan bahwa Cash Conversion Cycle (CCC) berpengaruh negatif terhadap Gross Profit ditolak. Walaupun nilai koefisien dari CCC negatif, tetapi hasil statistik menunjukkan bahwa pengaruh negatif tersebut tidak signifikan terhadap Gross Profit. Hal ini menyatakan bahwa penurunan CCC tidak memengaruhi kenaikan Gross Profit, dimana hasil ini berbeda dengan penelitian Lazaridis dan Tryfonidis (2006) dan penelitian Teruel dan Solano (2007) yang menyatakan bahwa Cash Conversion Cycle (CCC) berpengaruh negatif signifikan terhadap profitabilitas perusahaan. Namun, hasil pengujian hipotesis ini sesuai dengan penelitian Samiloglu dan Demigurnes (2008) yang menyatakan bahwa Cash Conversion Cycle (CCC) tidak berpengaruh negatif signifikan terhadap profitabilitas perusahaan.

Pada pengujian hipotesis kedua, diketahui bahwa hipotesis yang menyatakan bahwa Number of Days Account Receivable (NDAR) berpengaruh negatif terhadap Gross Profit diterima. Hal ini menyatakan bahwa penurunan NDAR akan mengakibatkan kenaikan Gross Profit, dan sebaliknya. Hal ini disebabkan semakin cepat piutang dibayarkan atau semakin kecil nilai NDAR, maka akan semakin cepat pula perusahaan akan memperoleh kas yang akan digunakan untuk dana modal kerja. Peningkatan modal kerja akan berdampak pada peningkatan kegiatan operasional perusahaan, yang pada akhirnya akan meningkatkan volume penjualan dan meningkatkan laba perusahaan. Hasil ini sesuai dengan penelitian Samiloglu dan Demirgunes (2008), penelitian Lazaridis dan Tryfonidis (2006), dan penelitian Teruel dan Solano (2007) yang menyatakan bahwa Number of Days Account Receivable $(N D A R)$ berpengaruh negatif secara signifikan terhadap profitabilitas perusahaan. Pada pengujian hipotesis ketiga, diperoleh hasil bahwa hipotesis yang menyatakan Number of Days Inventory (NDI) berpengaruh negatif terhadap Gross Profit diterima. Hal ini menyatakan bahwa penurunan NDI akan mengakibatkan kenaikan Gross Profit, dan sebaliknya. Hasil ini berbeda dengan penelitian Lazaridis dan Tryfonidis (2006) yang menyatakan bahwa Number of Days Inventory (NDI) tidak berpengaruh negatif signifikan terhadap Gross Profit. Akan tetapi, hasil ini sesuai dengan penelitian Samiloglu dan Demirgunes (2008) dan penelitian Teruel dan Solano (2007) yang menyatakan bahwa Number of Days Inventory (NDI) berpengaruh negatif secara signifikan terhadap profitabilitas perusahaan.

Pada pengujian hipotesis keempat, didapatkan hasil bahwa hipotesis yang menyatakan Number of Days Account Payable (NDAP) berpengaruh negatif terhadap Gross Profit diterima. Penurunan NDAP akan mengakibatkan kenaikan Gross Profit. Hal ini dikarenakan semakin cepat hutang dibayarkan kepada kreditor, atau semakin kecil nilai NDAP, akan meningkatkan kepercayaan kreditor kepada perusahaan, dan meningkatkan nilai dari perusahaan itu sendiri. Hal ini akan memudahkan perusahaan memperoleh dana modal kerja dari pihak ketiga. Peningkatan modal kerja tersebut akan digunakan untuk meningkatkan kegiatan operasional perusahaan, yang pada akhirnya akan meningkatkan volume penjualan dan juga meningkatkan laba yang dihasilkan oleh perusahaan. Hasil ini berbeda dengan penelitian Teruel dan Solano (2007) yang menyatakan bahwa Number of Days Account Payable (NDAP) tidak berpengaruh negatif secara signifikan terhadap profitabilitas perusahaan, tetapi sesuai dengan penelitian Lazaridis dan Tryfonidis (2006) yang menyatakan bahwa

Number of Days Account Payable (NDAP) berpengaruh negatif secara signifikan terhadap profitabilitas perusahaan.

\section{PENUTUP}

Penelitian ini bertujuan untuk melihat pengaruh antara manajemen modal kerja terhadap profitabilitas pada perusahaan-perusahaan dalam industri consumer goods yang terdaftar di BEI selama tahun 2006 - 2008. Variabel - variabel yang digunakan dalam penelitian ini adalah 1 variabel dependen berupa Gross Profit (NLGP); 3 variabel independen berupa Cash Conversion Cycle (CCC), Number of Days Account Receivable (NDAR), Number of Days Inventory (NDI), dan Number of Days 
Account Payable (NDAP); dan 3 variabel kontrol berupa ukuran perusahaan dilihat dari total asetnya (NLA), pertumbuhan penjualan (SGROWTH), dan rasio leverage (DEBT). Hipotesis pertama yang menyatakan bahwa Cash Conversion Cycle (CCC) berpengaruh negatif dan signifikan terhadap profitabilitas (Gross Profit) ditolak. Hal ini telah dibuktikan dengan hasil t-statistik (-1.495) > -t-tabel $(-1.66)$ dan nilai t-sig $(0.139)>\alpha(0.1)$. Hal ini juga menyatakan bahwa Hal ditolak atau H01 tidak ditolak. Hipotesis kedua yang menyatakan bahwa Number of Days Account Receivable (NDAR) berpengaruh negatif dan signifikan terhadap profitabilitas (Gross Profit) diterima. Hal ini telah dibuktikan dengan hasil t-statistik $(-1.821)<$-t-tabel $(-1.66)$ dan nilai t-sig $(0.072)<\alpha(0.1)$. Hal ini juga menyatakan bahwa $\mathrm{Ha} 2$ diterima atau $\mathrm{H} 02$ ditolak dalam tingkat $\alpha=10 \%$.

Hipotesis ketiga yang menyatakan bahwa Number of Days Inventory (NDI) berpengaruh negatif dan signifikan terhadap profitabilitas (Gross Profit) diterima. Hal ini telah dibuktikan dengan hasil t-statistik $(-1.744)<-$ t-tabel $(-1.66)$ dan nilai t-sig $(0.085)<\alpha(0.1)$. Hal ini juga menyatakan bahwa Ha3 diterima atau $\mathrm{H} 03$ ditolak dalam tingkat $\alpha=10 \%$. Hipotesis keempat yang menyatakan bahwa Number of Days Account Payable (NDAP) berpengaruh negatif dan signifikan terhadap profitabilitas (Gross Profit) diterima. Hal ini telah dibuktikan dengan hasil t-statistik $(-1.912)<-$ ttabel $(-1.66)$ dan nilai t-sig $(0.059)<\alpha(0.1)$. Hal ini juga menyatakan bahwa Ha3 diterima atau $\mathrm{H} 03$ ditolak dalam tingkat $\alpha=10 \%$.

\section{Simpulan}

Cash Conversion Cycle (CCC) tidak berpengaruh negatif dan signifikan terhadap profitabilitas (Gross Profit), sedangkan variabel lainnya yaitu Number of Days Account Receivable (NDAR), Number of Days Inventory (NDI), dan Number of Days Account Payable (NDAP) mempunyai pengaruh negatif dan signifikan terhadap profitabilitas (Gross Profit). Variabel komponen manajemen modal kerja yang digunakan dalam penelitian ini dan berpengaruh paling negatif dan signifikan terhadap profitabilitas (Gross Profit) adalah variabel Number of Days Account Payable (NDAP) dengan nilai t-sig sebesar 0.059. Dari keempat variabel yang digunakan dalam penelitian ini, satusatunya variabel yang tidak mempunyai pengaruh negatif dan signifikan terhadap profitabilitas adalah Cash Conversion Cycle (CCC) dengan nilai t-sig sebesar 0.139.

\section{DAFTAR PUSTAKA}

Lazaridis, I., \& Tryfonidis, D. (2006). The relationship between working capital management and profitability of listed companies in the Athens Stock Exchange.

Samiloglu, F., \& Demirgunes, K. (2008). The effect of working capital management on firm profitability: Evidence from Turkey. The International Journal of Applied Economic and Finance.

Teruel, P. J. G., \& Solano, P. M. (2006). Effect of working capital management on SME Proftability. 